\title{
DISKRIMINASI KELAS DAN GENDER TERHADAP PEREMPUAN BALI DALAM NOVEL TARIAN BUMI KARYA OKA RUSMINI
}

\author{
Uman Rejo
}

\author{
Email: umanrejo@yahoo.com \\ Program Studi Sastra Indonesia Jurusan Bahasa dan Sastra Indonesia Universita Negeri Surabaya \\ Alamat Koresponden: Jalan Lidah Wetan Surabaya 60213
}

\begin{abstract}
This paper discusses class and gender discrimination in Tarian Bumi, a novel written by Oka Rusmini (2007). Class and gender discrimination can be seen through the differences in actions, statuses, and positions between the brahmana class and the sudra class, and between the male and female characters, not only in domestic issues, but also in public issues. The differences in actions, statuses, and positions are manifested in the oppression of the lower class (sudra and female) by the stronger class (brahmana and male). This paper adopts a feminist approach to investigate the class and gender discrimination as found in the novel.
\end{abstract}

\section{Keywords}

Teori Feminis, Diskriminasi Kelas, Diskriminasi Gender, Perempuan Bali

\section{Pendahuluan}

Karya sastra adalah dunia yang baru. Ia lahir dan terbangun dari berbagai serpihan-serpihan peristiwa, fakta, dan imajinasi pengarangnya. Banyak hal dan sisi hidup yang selama ini terbengkalai untuk dipungut, dibedah, kemudian direkonstruksi dalam sebuah karya sastra. Sebagai dunia baru, karya sastra tidak hanya menawarkan adanya lanskap hidup baru, pemandangan yang baru, atau pun warna-warni yang menggeriap baru. Tapi dunia baru dalam karya sastra juga memerlukan cakrawala pemikiran baru.

Karya sastra dapat menambah kearifan dan kebijaksanaan dalam kehidupan. Menurut Jassin (1983: 4) karya sastra akan selalu menarik perhatian karena mengungkapkan penghayatan manusia yang paling dalam, dalam perjalanan hidupnya di segala zaman, di segala tempat yang ada di dunia ini. Melalui sastra sebagai hasil seni, pembaca dapat memasuki pengalaman bangsa, sejarah, dan masyarakatnya untuk menyelami apa yang pernah dipikirkan dan dirasakan.

Sebuah karya sastra merupakan kebulatan yang utuh, khas, dan bisa berdiri sendiri, serta merupakan dunia keindahan dalam wujud bahasa yang telah dipenuhi dengan kehidupan dan realitas. Menurut Kurnia (2004: 227; 2009: 82) menyatakan bahwa karya sastra merupakan produk budaya. Karya sastra diyakini dapat mengkomunikasikan suatu pengalaman batin manusia berupa permasalahan kemanusiaan yang lahir dari pengarang sebagai pencipta, sekaligus sebagai bagian dari kelompok masyarakat setempat. Permasalahan yang diajukan oleh pengarang dapat bersifat permasalahan setempat, dapat juga bersifat kreasi rekaan yang berada dalam anganangan pengarang. Kenyataan yang berada dalam angan-angan pengarang memberi kemungkinan dan keleluasaan untuk memperkenalkan pembaca pada dunia lain dengan sistem nilai kehidupan yang berbeda dengan sistem nilai kehidupan masyarakat setempat. Karya sastra lewat imajinasi dan konsep kehidupan pengarang dapat merupakan sarana untuk mendialogkan sisi lain pemikiran tentang kehidupan dan budaya masyarakat setempat. 


\section{Penutup}

Dalam konteks Tarian Bumi, sistem perkastaan di Bali yang hierarkis dan patriarkis membawa dampak-dampak negatif terhadap kaum lemah, yaitu kelas sudra dan kaum perempuan. Dampakdampak negatif itu terlihat pada diskriminasi yang kental baik diskriminasi kelas maupun diskriminasi gender. Diskriminasi kelas sangat jelas dalam perbedaan peran, status, dan posisi antara kelas yang berkuasa, yaitu bramana dengan kelas yang tidak memiliki kekuasaan yaitu sudra.

Demikian pula dengan diskriminasi gender. la selalu muncul baik dalam kalangan bangsawan- brahmana, maupun dalam kalangan orang kebanyakan-sudra. Apabila dalam kelas brahmana ada lapis-lapis kadar kebangsawanan, dalam kelas sudra pun ada meskipun tersamar.

Dengan demikian, pemberontakan perempuan terhadap diskriminasi kelas dan gender dalam Tarian Bumi, tidak sepenuhnya memihak kepada golongan lemah yaitu sudra dan perempuan. Di sini, "pemberontak" masih berada pada situasi ambivalen, antara menentang dan menerima. Dua kubu yang bertentangan itu sama-sama memiliki sisi negatif rneskipun lebih cenderung pada kubu atau golongan kuat

\section{DAFTAR PUSTAKA}

Atmadja, Nengah Bawa. 2010. Ajeg Bali: Gerakan, Identitas Kultural, dan Globalisasi. Yogyakarta: LKiS.

Bagus, I Gusti Ngurah. 2002. "Kebudayaan Bali" dalam Manusia dan Kebudayaan di Indonesia. Koentjaraningrat (editor). Jakarta: Djambatan.

Budianta, Melani. 2002. "Pendekatan Feminisme terhadap Wacana" dalam Analisis Wacana. Yogyakarta: Kamal.

Chasanah, Ida Nurul. 2011. "Membaca Tubuh dalam Rangkaian Sastra Indonesia" dalam Seminar Femininitas dan Maskulinitas dalam Karya-karya Nh. Dini di Auditorium Fakultas Ilmu Budaya Universitas Airlangga Surabaya, 2 Desember 2011.

Damono, Sapardi Djoko. 2002a. Pegangan Penelitian Sosiologi Sastra. Jakarta: Pusat Bahasa.

. 2002b. "Pengarang, Karya Sastra, dan Pembaca" dalam Makalah Pelatihan Teori dan Kritik Sastra, PPPG Bahasa di Universitas Indonesia pada 27-30 Mei 2002.

Darsono. 1996. "Citra Wanita dalam Tiga Novel Sastra Indonesia Pasca-1990" dalam Seminar Wanita dan Sastra di Fakultas Sastra Universitas Kristen Petra Surabaya, 26-27 Agustus 1996.

Djajanegara, Soenarjati. 2003. Kritik Sastra Feminis: sebuah Pengantar. Jakarta: PT Gramedia Pustaka Utama.

. 2004. "Dari Marginal ke Mainstream: Perkembangan Penulis Wanita di Amerika" dalam Menyoal Sastra Marginal. Ibnu Wahyudi (editor). Jakarta: Wedatama Widya Sastra.

Endraswara, Suwardi. 2008. Metodologi Penelitian Sastra: Epistemologi, Model, Teori, dan Aplikasi (Edisi Revisi). Yogyakarta: Media Pressindo.

Handayani, Trisakti dan Sugiarti. 2010. Konsep dan Teknik Penelitian Gender. Malang: UMM Press.

Jackson, Stevi. 2009. “Teori Sosial Feminis” dalam Pengantar Teori-teori Feminis Kontemporer. Stevi Jackson dan Jackie Jones (editor). Yogyakarta: Jalasutra.

Jassin, H.B. 1983. Sastra Indonesia sebagai Warga Sastra Dunia. Jakarta: Gramedia.

Kurnia, Fabiola Dharmawanti. 2004. "Unsur Dualistik dalam Wacana Seksual Fiksi Bali: Kajian Intertekstualitas". Dalam Prasasti, Jurnal Ilmu Sastra dan Seni, Vol. 54, Tahun XIV Agustus 2004 halaman 227-254. 
2006. Bali dalam Dua Fiksi Oka Rusmini: Konkretisasi Budaya dalam Sastra. Disertasi tidak diterbitkan. Depok: Program Studi Ilmu Susastra Fakultas Ilmu Pengetahuan Budaya Universitas Indonesia.

2009. Pelangi Sastra dan Budaya. Surabaya: Unesa University Press.

Liliweri, Alo. 2009. Prasangka dan Konflik: Komunikasi Lintas Budaya Masyarakat Multikultur. Yogyakarta: LKiS.

Mansur, Fakih. 2001. Analisis Gender dan Transformasi Sosial. Yogyakarta: Pustaka Pelajar.

Nasution, Ikhwanudin. 2009. Sastra dan Globalisasi: Tantangan bagi Estetika dalam Dunia Kritik Sastra di Indonesia. Pidato Pengukuhan Jabatan Guru Besar Tetap dalam Bidang Ilmu Kritik Sastra pada Fakultas Sastra Universitas Sumatera Utara di Medan Sabtu, 3 Oktober 2009.

Ratna, Nyoman Kutha. 2004. Teori, Metode, dan Teknik Penelitian Sastra: dari Strukturalisme hingga Postrukturalisme. Yogyakarta: Pustaka Pelajar.

Rusmini, Oka. 2007. Tarian Bumi: sebuah Novel. Jakarta: PT Gramedia Pustaka Utama.

Sugihastuti. 2000. Wanita di Mata Wanita: Perspektif Sajak-sajak Toety Heraty. Bandung: Nuansa. dan Suharto. 2002. Kritik Sastra Feminis: Teori dan Aplikasinya. Yogyakarta: Pustaka Pelajar.

2009. Rona Bahasa dan Sastra Indonesia: Tanggapan Penutur dan Pembacanya. Yogyakarta: Pustaka Pelajar.

dan Itsna Hadi Saptiawan. 2010. Gender dan Inferioritas Perempuan: Praktik Kritik Sastra Feminis. Yogyakarta: Pustaka Pelajar.

Sutarto, Ayu. 2010. "Harga Perempuan dalam Cerita Ande-ande Lumut dan Dewi Sri Tanjung" dalam Rona Budaya: Festchrift untuk Sapardi Djoko Damono. Riris K. Toha Sarumpaet dan Melani Budianta (editor). Jakarta: Yayasan Pustaka Obor Indonesia.

Triadnyani, I Gusti Ayu Agung Mas. 2010. "Perempuan di Mata Oka Rusmini: Telaah Atas Kenanga dan Sagra" dalam Rona Budaya: Festchrift untuk Sapardi Djoko Damono. Riris K. Toha Sarumpaet dan Melani Budianta (editor). Jakarta: Yayasan Pustaka Obor Indonesia.

Wiyatmi. 2009. "Fenomena Seks dalam Novel Indonesia Mutakhir Karya Pengarang Perempuan: Kajian Kritik Sastra Feminis" dalam Pengantar Kajian Sastra. Yogyakarta: Pustaka Book Publisher. 